\title{
Rheumatoid factor, but not anti-cyclic citrullinated peptide antibodies, is modulated by infliximab treatment in rheumatoid arthritis
}

\author{
L De Rycke, X Verhelst, E Kruithof, F Van den Bosch, I E A Hoffman, \\ E M Veys, F De Keyser \\ r
}

Ann Rheum Dis 2005;64:299-302. doi: 10.1136/ard.2004.023523

Objectives: To analyse the effect of infliximab on $\lg M$ rheumatoid factor (RF) and anti-cyclic citrullinated peptide (CCP) antibodies, and determine whether baseline autoantibody titres (IgM RF and anti-CCP antibodies) are associated with changes in acute phase reactants.

Patients and methods: 62 patients with refractory RA were treated with infliximab combined with methotrexate. At baseline and week 30 , serum samples were tested for IgM RF by two agglutination assays, and for anti-CCP antibodies by an ELISA. Percentage change in $C$ reactive protein (CRP) and erythrocyte sedimentation rate (ESR) was calculated. Results: At baseline and week 30 RF titres were reduced significantly during infliximab treatment $(p<0.001$ and $p=0.038$, respectively), whereas anti-CCP antibodies were unchanged $(p=0.240)$. Baseline IgM RF titres, but not antiCCP antibodies, correlated inversely with changes in CRP and ESR during treatment. Patients with a marked decrease in acute phase reactants had lower IgM RF titres than those with a smaller decrease in CRP and ESR; no significant differences were found for anti-CCP antibodies.

Conclusion: The differential effect of infliximab treatment on $\operatorname{lgM} R F$ and anti-CCP antibodies, and the different predictive value on changes in acute phase reactants during infliximab treatment support the existing evidence that RF and anti-CCP antibodies are independent autoantibody systems in RA.

A lthough the precise aetiology of rheumatoid arthritis (RA) remains elusive, evidence for autoimmunity is strong because several autoantibodies are associated with the disease. Besides the rheumatoid factor (RF), another group of autoantibodies was detected in the serum of patients with RA: the anti-cyclic citrullinated peptide (anti-CCP) antibodies. Recently, we compared the diagnostic value of the $\mathrm{RF}$ and anti-CCP antibodies in a consecutive cohort of patients with inflammatory joint symptoms (patients with and without RA) at a specificity of at least $98.5 \%$, and we concluded that the anti-CCP antibodies were more sensitive than the RF (sensitivity anti-CCP antibodies $54.2-73.7 \% v$ sensitivity RF $12.8 \%) .^{1}$ Although there is an important overlap between the presence of RF and anti-CCP antibodies in the serum of patients with RA, evidence has suggested that the RF and anti-CCP antibodies are two separate autoantibody systems: (a) anti-CCP antibodies are associated with the shared epitope, ${ }^{1-3}$ whereas the RF is not associated or less associated with the presence of the shared epitope ${ }^{1}$; and $(b)$ extra-articular manifestations are related to the $\mathrm{RF}^{1}$ and not to anti-CCP antibodies. ${ }^{12}$

A correlation between RF titres and clinical disease activity has been reported, ${ }^{45}$ because RF titres decrease with successful treatment, particularly methotrexate or parenteral gold, this suggests an indirect link with disease activity. ${ }^{4}$ Because infliximab treatment (tumour necrosis factor $\alpha$ ( $\mathrm{TNF} \alpha$ ) blockade) has proved to be effective in the treatment of patients with refractory $\mathrm{RA}^{7}$ and because we previously demonstrated that infliximab treatment induces new antibody reactivities, leading to antinuclear antibodies and antidsDNA antibodies, ${ }^{8}$ this study aimed at analysing the effect of infliximab treatment on pre-existing autoimmune profiles (IgM RF and anti-CCP antibodies). Furthermore, we investigated whether baseline IgM RF and anti-CCP antibodies are associated with changes in acute phase reactants ( $\mathrm{C}$ reactive protein (CRP) and erythrocyte sedimentation rate (ESR)) during infliximab treatment.

\section{PATIENTS AND METHODS \\ Patients and samples}

Sixty two patients (24 men and 38 women; mean age at baseline 53.9 years (range 32-76)) with refractory RA, treated with infliximab at one centre (Department of Rheumatology, Ghent University Hospital, Ghent, Belgium) as part of an expanded access programme, were included in this study. All patients fulfilled the American College of Rheumatology classification criteria for RA. ${ }^{9}$ They received $3 \mathrm{mg} / \mathrm{kg}$ infliximab intravenously at weeks $0,2,6$, and every 8 weeks thereafter in combination with methotrexate. After 30 weeks of infliximab treatment, all patients showed a clinical improvement of at least $20 \%$ according to American College of Rheumatology response criteria. ${ }^{10}$

Serum samples were collected before infusion at baseline and at week 30 , and stored at $-20^{\circ} \mathrm{C}$ until further analysis. Serum samples were collected after informed consent from the patient and approval by the local ethics committee had been obtained.

\section{Detection of IgM RF}

$\lg M$ RF assay using particles sensitised with rabbit $\lg G$

This agglutination assay uses gelatin particles sensitised with denatured rabbit IgG (SERODIA-RA, Fuijrebio Inc, Tokyo, Japan). After incubation with progressively diluted human serum samples, the plates were inspected for observable agglutination.

$\lg M$ RF assay using particles sensitised with human $\lg G$

This assay is based on latex particles sensitised with human IgG (RFscan Latex assay, BD Diagnostic Systems, Sparks, Maryland, USA). After incubation with progressively diluted human serum samples, the plates were inspected for observable agglutination.

Abbreviations: anti-CCP, anti-cyclic citrullinated peptide; CRP, C reactive protein; $E S R$, erythrocyte sedimentation rate; $R A$, rheumatoid arthritis; RF, rheumatoid factor; $\mathrm{TNF} \alpha$, tumour necrosis factor $\alpha$ 


\begin{tabular}{|c|c|c|c|c|}
\hline Cut off point & $\begin{array}{l}\text { Patients } \\
\text { (n) }\end{array}$ & Baseline & Week 30 & p Value \\
\hline \multicolumn{5}{|c|}{ IgM RF (assay using particles sensitised with rabbit lgG) } \\
\hline$\geqslant 40$ & 54 & $320(40-5120)$ & $160(0-5120)$ & $<0.001$ \\
\hline$\geqslant 80$ & 48 & $320(80-5120)$ & $160(0-5120)$ & $<0.001$ \\
\hline$\geqslant 160$ & 41 & $320(160-5120)$ & $160(0-5120)$ & $<0.001$ \\
\hline Total cohort & 62 & $160(0-5120)$ & $160(0-5120)$ & $<0.001$ \\
\hline \multicolumn{5}{|c|}{ IgM RF (assay using particles sensitised with human lgG) } \\
\hline$\geqslant 40$ & 55 & $160(40-5120)$ & $160(0-5120)$ & 0.038 \\
\hline$\geqslant 80$ & 46 & $320(80-5120)$ & $160(0-5120)$ & 0.017 \\
\hline$\geqslant 160$ & 39 & $320(160-5120)$ & $160(0-5120)$ & 0.023 \\
\hline Total cohort & 62 & $160(0-5120)$ & $160(0-5120)$ & 0.038 \\
\hline \multicolumn{5}{|c|}{ Anti-CCP antibodies } \\
\hline$>50 \mathrm{U}^{*}$ & 41 & $880(65-5236)$ & $719(54-8802)$ & 0.530 \\
\hline Total cohort & 62 & $535(5-5236)$ & $447(7-8802)$ & 0.240 \\
\hline
\end{tabular}

*Manufacturer's cut off point. Median values (range) are given. Wilcoxon signed rank test.

\section{Detection of anti-CCP antibodies}

The anti-CCPl enzyme linked immunosorbent assay (ELISA; Immunoscan RA, Eurodiagnostica, Arnhem, The Netherlands) uses plates coated with highly purified synthetic peptides containing citrulline residues. The test was performed according to the manufacturer's instructions.

\section{Statistical analysis}

Statistical analysis was performed using SPSS 10.0 software (SPSS, Chicago, IL). We used the Wilcoxon signed rank test for paired analysis and the Mann-Whitney $U$ test for comparison of patient groups with and without a marked decrease of the acute phase reactants. Correlations were sought using Spearman's correlation coefficients $\left(r_{\mathrm{s}}\right)$. Values of $\mathrm{p}<0.05$ were considered significant.

\section{RESULTS}

IgM RF, but not anti-CCP antibodies, is modulated by infliximab treatment

IgM RF assay using particles sensitised with rabbit $\lg G$

As shown in table 1 for the total cohort and for different cut off points, the RF titre was significantly reduced during infliximab treatment. Furthermore, the majority of patients with RA showed a decrease in RF titre $(n=32)$, including a reduction of at least two titre steps in 9/32 patients, whereas in nine patients the RF titre increased, including an increase of at least two titre steps in only one patient, and in 21 patients the RF titres did not change.

\section{IgM RF assay using particles sensitised with human $\lg G$}

For this alternative RF assay, a similar, significant reduction in RF titre was observed (as illustrated for the total cohort and for different cut off points in table 1). The majority of patients had a decrease in RF titre $(n=33)$, including a reduction of at least two titre steps in 19/33 patients, whereas the RF titre increased in 15 patients, including an increase of at least two titre steps in $8 / 15$ patients, and remained unchanged in 14 other patients.

\section{Anti-CCP antibodies}

A comparison of the concentrations of anti-CCP antibodies at baseline and after 30 weeks of infliximab treatment showed no significant differences, indicating that anti-CCP antibodies are not modulated by infliximab treatment (as given for the total cohort and for the manufacturer's cut off point in table 1). Moreover, 38/62 patients with RA showed a decrease in concentrations of anti-CCP antibodies, whereas $24 / 62$ patients had an increase after infliximab treatment. Only 23/38 patients had a marked reduction (at least $20 \%$ decrease) in anti-CCP antibody levels, whereas in 13/24 patients the concentrations of anti-CCP antibodies increased by at least $20 \%$.

Furthermore, we observed no correlations between changes in RF and changes in anti-CCP antibodies during infliximab treatment (for RF assay using particles sensitised with rabbit IgG: $r_{\mathrm{s}}=0.015, \mathrm{p}=0.908$; for $\mathrm{RF}$ assay using particles sensitised with human IgG: $r_{\mathrm{s}}=-0.083, \mathrm{p}=0.529$ ), supporting the hypothesis that RF and anti-CCP antibodies are two independent autoantibody systems in RA.

\section{IgM RF, but not anti-CCP antibodies, is associated with changes in acute phase reactants during infliximab treatment \\ We further investigated whether IgM RF and anti-CCP antibodies at baseline are predictive of the biological response during infliximab treatment. In patients with increased CRP $(>10 \mathrm{mg} / \mathrm{l}, \mathrm{n}=44)$ or ESR $(>20 \mathrm{~mm} / \mathrm{lst} \mathrm{h}, \mathrm{n}=37)$, we analysed the correlations between titres of autoantibodies at baseline and the percentage change in acute phase reactants}

\begin{tabular}{|c|c|c|c|c|}
\hline & \multicolumn{2}{|c|}{ \% change in CRP } & \multicolumn{2}{|c|}{ \% change in ESR } \\
\hline & $r_{\mathrm{s}}$ & $\mathrm{p}$ Value & $r_{\mathrm{s}}$ & p Value \\
\hline $\begin{array}{l}\text { IgM RF (assay using particles sensitised with rabbit } \\
\operatorname{lgG} \text { ) }\end{array}$ & -0.282 & 0.063 & -0.307 & 0.064 \\
\hline $\begin{array}{l}\text { lgM RF(assay using particles sensitised with human } \\
\operatorname{lgG} \text { ) }\end{array}$ & -0.305 & 0.044 & -0.385 & 0.019 \\
\hline Anti-CCP antibodies & -0.028 & 0.859 & -0.158 & 0.350 \\
\hline
\end{tabular}


Table 3 Comparison of the baseline IgM RF titres and concentrations of anti-CCP antibodies between patients with and without a marked decrease in acute phase reactants (CRP and ESR)

\begin{tabular}{llll}
\hline & $\begin{array}{l}\text { Patients with a marked } \\
\text { decrease in acute } \\
\text { phase reactants* } \\
(\mathbf{n}=19)\end{array}$ & $\begin{array}{l}\text { Patients without a } \\
\text { marked decrease in } \\
\text { acute phase reactants } \\
(\mathbf{n}=15)\end{array}$ & p Value \\
\hline $\begin{array}{l}\text { IgM RF (assay using particles sensitised } \\
\text { with rabbit lgG) }\end{array}$ & $320(0-1280)$ & $320(80-5120)$ & 0.036 \\
$\begin{array}{l}\text { IgM RF (assay using particles sensitised } \\
\text { with human lgG) }\end{array}$ & $160(0-640)$ & $320(40-5120)$ & 0.023 \\
Anti-CCP antibodies (U) & $101(12-2233)$ & $1017(5-5003)$ & 0.179 \\
\hline *At least 20\% decrease in CRP and ESR. Median values (range) are given. Mann-Whitney U test.
\end{tabular}

during infliximab treatment. Table 2 shows that a significant inverse correlation was found between the baseline IgM RF titres measured by an agglutination assay using particles sensitised with human IgG and the percentage change in CRP and ESR, indicating that patients with high baseline IgM RF titres have a less pronounced decrease in acute phase reactants. This was further confirmed by a similar trend using the other RF assay (table 2). In contrast, baseline concentrations of anti-CCP antibodies did not correlate significantly with changes in CRP or ESR during infliximab treatment (table 2).

Furthermore, we analysed the baseline autoantibody titres in the patients with and without a marked decrease of at least 20\% in CRP and ESR during infliximab treatment. We observed significantly lower IgM RF titres in the patients with a marked decrease in acute phase reactants than in those with a less pronounced decrease in CRP and ESR (table 3). Again, no statistically significant differences were found in baseline concentrations of anti-CCP antibodies (table 3).

\section{DISCUSSION}

The importance of the different RA associated antibodies as diagnostic markers for RA has been extensively analysed, and a valid comparison clearly indicates that anti-CCP antibodies show a better diagnostic performance than RF. ${ }^{11-13}$ However, few data are available on the relationship between antibody titres and response to treatment. Some studies describe a decrease in RF titres during successful treatment with methotrexate or parenteral gold, ${ }^{46}$ but until now, changes in RF titres during anti-TNF $\alpha$ treatment have only been analysed in two studies (by Maini et al and Charles et al), who reported a decrease in RF titres in infliximab treated patients with RA. ${ }^{14} 15$

Our study describes the effect of TNF $\alpha$ blockade on both the RF and anti-CCP antibodies in the same cohort of patients with RA. Interestingly, a clearly different effect of infliximab treatment on the IgM RF and anti-CCP antibodies was found: RF titres decreased significantly (confirming the results reported by Maini et al and Charles et al), but concentrations of anti-CCP antibodies did not change. These remarkable findings indicate that anti-CCP antibodies could act as a disease-specific marker for RA and are not modulated by infliximab treatment, whereas IgM RF titres could be related to disease activity as suggested by the decrease in IgM RF titres during infliximab treatment.

Another important topic in view of these new biological treatments such as TNF $\alpha$ blockade is the identification of biomarkers that predict response to treatment. When analysing the RA associated autoantibodies in relation to changes in acute phase reactants, we observed an inverse correlation between the baseline $\operatorname{IgM}$ RF titres and the changes in CRP and ESR. In contrast, the baseline concentrations of anti-CCP antibodies did not correlate significantly with the changes in acute phase reactants during infliximab treatment. In other words, patients with RA with high baseline IgM RF titres have a less pronounced decrease of CRP and ESR. These findings were confirmed by the lower baseline RF titres in patients with a marked decrease in acute phase reactants compared with those with a less pronounced decrease in CRP and ESR.

In conclusion, both the differential effect of infliximab treatment on IgM RF and the anti-CCP antibodies, and the different predictive value on the changes in acute phase reactants during infliximab treatment add support to the existing evidence that RF and anti-CCP antibodies are two different, independent autoantibody systems in RA. Our data indicate that the RF and anti-CCP antibodies may provide different and, eventually, complementary biological information on the disease process in RA.

\section{ACKNOWLEDGEMENTS}

We thank Jeanine Discart for excellent technical assistance. This work was supported by a grant from the "Vlaams instituut voor de bevordering van het wetenschappelijk-technologisch onderzoek in de industrie" (IWT/SB/11127) and a research grant from the "Bijzonder Onderzoeksfonds", Ghent University.

\section{Authors' affiliations \\ L De Rycke, X Verhelst, E Kruithof, F V den Bosch, I E A Hoffman, E M Veys, F D Keyser, Department of Rheumatology, Ghent University Hospital, Ghent, Belgium}

Correspondence to: Dr L De Rycke, Department of Rheumatology, Ghent University Hospital, De Pintelaan 185, 9000 Ghent, Belgium; leen. derycke@Ugent.be

\section{Accepted 16 May 2004}

Published Online First 27 May 2004

\section{REFERENCES}

1 De Rycke L, Peene I, Hoffman IEA, Kruithof E, Union A, Meheus L, et al. Rheumatoid factor and anti-citrullinated protein antibodies in rheumatoid arthritis: diagnostic value, associations with radiological progression rate, and extra-articular manifestations. Ann Rheum Dis 2004:63:1587-93.

2 Bas S, Perneger TV, Mikhnevitch E, Seitz M, Tiercy JM, Roux-Lombard P, et al. Association of rheumatoid factors and anti-filaggrin antibodies with severity of erosions in rheumatoid arthritis. Rheumatology (Oxford) 2000;39:1082-8.

3 Hill JA, Southwood S, Sette A, Jevnikar A, Bell DA, Cairins E. Cutting edge: the conversion of arginine to citrulline allows for a high affinity peptide interaction with the rheumatoid arthritis-associated HLA-DRB ${ }^{*} 0401$ MHC class II molecule. J Immunol 2003;171:538-41.

4 Alarcon GS, Schrohenloher RE, Bartolucci AA, Ward JR, Williams HJ, Koopman WJ. Suppression of rheumatoid factor production by methotrexate in patients with rheumatoid arthritis. Evidence for differential influences of therapy and clinical status on $\lg M$ and $\lg \mathrm{A}$ rheumatoid factor expression. Arthritis Rheum 1990;33:1156-61.

5 Cush JJ, Lipsky PE, Postlethwaite AE, Schrohenloher RE, Saway A, Koopman WJ. Correlation of serologic indicators of inflammation with effectiveness of nonsteroidal antiinflammatory drug therapy in rheumatoid arthritis. Arthritis Rheum 1990;33:19-28. 
6 Olsen NJ, Teal GP, Brooks. IgM-rheumatoid factor and responses to secondline drugs in rheumatoid arthritis. Agents Actions 1991;34:169-71.

7 Feldmann M, Maini RN. Discovery of TNF- $\alpha$ as a therapeutic target in rheumatoid arthritis: preclinical and clinical studies. Joint Bone Spine 2002;69:12-18

8 De Rycke L, Kruithof E, Van Damme N, Hoffman IEA, Van Den Bossche N, Van den Bosch F, et al. Antinuclear antibodies following infliximab treatment in patients with rheumatoid arthritis and spondyloarthropathy. Arthritis Rheum 2003:48:1015-23

9 Arnett FC, Edworthy SM, Bloch DA McShane DJ, Fries JF, Cooper NS, et al. The American Rheumatism Association 1987 revised criteria for the classification of rheumatoid arthritis. Arthritis Rheum 1988;31:315-24.

10 Felson DT, Anderson JJ, Boers M, Bombardier C, Furst D, Goldsmith C, et al. American College of Rheumatology. Preliminary definition of improvement in rheumatoid arthritis. Arthritis Rheum 1995;38:727-35.

11 Bas S, Perneger TV, Seitz M, Tiercy JM, Roux-Lombard P, Guerne PA. Diagnostic test for rheumatoid arthritis: comparison of anti-cyclic citrullinated peptide antibodies, anti-keratin antibodies and $\lg M$ rheumatoid factors. Rheumatology (Oxford) 2002;41:809-14.

12 Schellekens GA, Visser H, de Jong BAW, van den Hoogen FHJ, Hazes JMW Breedveld FC, et al. The diagnostic properties of rheumatoid arthritis antibodies recognizing a cyclic citrullinated peptide. Arthritis Rheum 2000;43:155-63.

13 Suzuki K, Sawada T, Murakami A, Matsui T, Tohma S, Nakazono K, et al. High diagnostic performance of ELISA detection of antibodies to citrullinated antigens in rheumatoid arthritis. Scand J Rheumatol 2003:32:197-204.

14 Maini R, William St Clair E, Breedveld F, Furst D, Kalden J, Weisman M, et al. Infliximab (chimeric anti-tumour necrosis factor $\alpha$ monoclonal antibody) versus placebo in rheumatoid arthritis patients receiving concommitant methotrexate: a randomised phase III trial. Lancet 1999:354:1932-9.

15 Charles P, Smeenk RJT, De Jong J, Feldmann M, Maini R. Assessment of antibodies to double-stranded DNA induced in rheumatoid arthritis patients following treatment with infliximab, a monoclonal antibody to tumor necrosis factor $\alpha$. Arthritis Rheum 2000;11:2383-90.

\section{Clinical Evidence-Call for contributors}

Clinical Evidence is a regularly updated evidence-based journal available worldwide both as a paper version and on the internet. Clinical Evidence needs to recruit a number of new contributors. Contributors are healthcare professionals or epidemiologists with experience in evidence-based medicine and the ability to write in a concise and structured way.

Areas for which we are currently seeking authors:

- Child health: nocturnal enuresis

- Eye disorders: bacterial conjunctivitis

- Male health: prostate cancer (metastatic)

- Women's health: pre-menstrual syndrome; pyelonephritis in non-pregnant women

However, we are always looking for others, so do not let this list discourage you.

Being a contributor involves:

- Selecting from a validated, screened search (performed by in-house Information Specialists) epidemiologically sound studies for inclusion.

- Documenting your decisions about which studies to include on an inclusion and exclusion form, which we keep on file.

- Writing the text to a highly structured template (about 1500-3000 words), using evidence from the final studies chosen, within 8-10 weeks of receiving the literature search.

- Working with Clinical Evidence editors to ensure that the final text meets epidemiological and style standards.

- Updating the text every six months using any new, sound evidence that becomes available. The Clinical Evidence in-house team will conduct the searches for contributors; your task is simply to filter out high quality studies and incorporate them in the existing text.

- To expand the topic to include a new question about once every 12-18 months.

If you would like to become a contributor for Clinical Evidence or require more information about what this involves please send your contact details and a copy of your CV, clearly stating the clinical area you are interested in, to Klara Brunnhuber (kbrunnhuber@ bmigroup.com).

\section{Call for peer reviewers}

Clinical Evidence also needs to recruit a number of new peer reviewers specifically with an interest in the clinical areas stated above, and also others related to general practice. Peer reviewers are healthcare professionals or epidemiologists with experience in evidence-based medicine. As a peer reviewer you would be asked for your views on the clinical relevance, validity, and accessibility of specific topics within the journal, and their usefulness to the intended audience (international generalists and healthcare professionals, possibly with limited statistical knowledge). Topics are usually 1500-3000 words in length and we would ask you to review between 2-5 topics per year. The peer review process takes place throughout the year, and our turnaround time for each review is ideally 10-14 days.

If you are interested in becoming a peer reviewer for Clinical Evidence, please complete the peer review questionnaire at www.clinicalevidence.com or contact Klara Brunnhuber (kbrunnhuber@bmjgroup.com). 